\title{
STRATEGI KEPALA DESA DALAM MENINGKATKAN KINERJA PEGAWAI DI KANTOR DESA NAGARA KECAMATAN KIBIN KABUPATEN SERANG
}

\author{
Riyadil Jinan', Syamsul Hidayat ${ }^{2}$, Saepudin ${ }^{3}$ \\ ${ }^{1,2,3}$ Universitas Bina Bangsa \\ jinanriyadil74@gmail.com
}

\begin{abstract}
ABSTRAK
Kepala Desa yaitu Penguasa tertinggi di Desa dan sebagai Pemimpin Formal maupun Informal, Pemimpin yang setiap waktu berada ditengah-tengah Rakyat yang dipimpinnya. Pentingnya kinerja pegawai pada suatu organisasi pemerintahan seperti Kantor Desa Nagara merupakan salah satu unsur dalam pencapaian tujuan pelayanan yang maksimal kepada masyarakat.

Tentunya dalam hal ini Strategi Kepala Desa Nagara tersebut sangatlah berpengaruh terhadap Kinerja Pegawai. Namun berbanding terbalik dengan Kinerja yang dilakukan oleh oknum Pegawai Kantor Desa Nagara ini. Kinerja yang tidak optimal pastinya akan berpengaruh terhadap pelayanan kepada masyarakat. Tentunya masyarakat tidak puas atas pelayanan yang telah diberikan oleh pegawai.

Tujuan penelitian ini adalah untuk mengetahui Strategi Kepala Desa Nagara dalam meningkatkan Kinerja Pegawai di Kantor Desa Nagara Kecamatan Kibin Kabupaten Serang. Jenis penelitian yang digunakan peneliti di dalam penelitian ini adalah penelitian kualitatif dengan pendekatan deskriptif dengan berlandaskan pada teori fenomenologi. Alat pengumpul data atau instrumen adalah peneliti sendiri yang langsung terjun ke lapangan. Teknik pengumpulan data dalam penelitian ini adalah wawancara, observasi, dokumentasi, kepustakaan. Informan dalam penelitian ini adalah dari pegawai yang bekerja di Kantor Desa Nagara, informan berjumlah 4 orang yaitu Kepala Desa sebagai key informan, KAUR Perencanaan, KASI Pelayanan dan KAUR Umum.

Hasil dari penelitian ini adalah Rapat rutin internal Kantor Desa sudah terlaksana dengan baik meskipun tidak menentu waktunya bisa seminggu sekali dan bisa sebulan sekali, struktur organisasi sudah ada, sarana dan prasarana sudah lengkap, berkaitan dengan disiplin pegawai sudah bagus, untuk reward dan punishment hanya ada tunjangan lebih jika ada pegawai yang berprestasi, kualitas Sumber Daya Manusia (SDM) sudah bagus, sudah ada kemitraan dengan instansi lain yaitu mengadakan kerjasama dengan Dinas Pertanian dan adanya pelatihan yang dilakukan berupa pelatihan dengan Badan Permusyawaratan Desa (BPD).
\end{abstract}

Kata kunci : Strategi, Kepala Desa, Kinerja

\begin{abstract}
The Village head is the highest authority in the village and as a formal or informal leader, a leader who is always in the midst of the people. The importance of employee performance in a government organization such as the Nagara Village Office is one element in achieving maximum service goals to the community.

Of course, in this case the Nagara Village Head's Strategy is very influential on Employee Performance. However, it is inversely proportional to the performance of this Nagara Village Office employee. Performance that is not optimal will certainly affect services to the community. Of course, people are not satisfied with the services that have been provided by employees.
\end{abstract}


Prosiding The 1st National Conference on Applied Business, Education, \& Technology (NCABET)"

Unversitas Bina Bangsa 2021

DOI Article : 10.46306/ncabet.v1i1.1

The purpose of this study was to determine the Strategy of the Head of Nagara Village in improving Employee Performance at the Nagara Village Office, Kibin District, Serang Regency. The type of research used by researchers in this study is qualitative research with a descriptive approach based on phenomenological theory. The data collection tool or instrument is the researcher himself who goes directly to the field. Data collection techniques in this study are interviews, observation, documentation, literature. The informants in this study were from employees who worked at the Nagara Village Office, there were 4 informants, namely the Village Head as key informant, KAUR Planning, KASI Services and General KAUR.

The results of this study are the Village Office internal routine meetings have been carried out well, although the time is uncertain, it can be once a week or once a month, the organizational structure already exists, the facilities and infrastructure are complete, related to employee discipline is good, for rewards and punishments there are only more benefits if there are employees who excel, the quality of human resources is good, there are already partnerships with other agencies, namely collaborating with the Department of Agriculture and training in the form of training with Village Consultative body.

Keywords : Strategy, Village Head, Performance

\section{PENDAHULUAN}

Suatu Organisasi dibentuk untuk mencapai suatu tujuan tertentu. Setiap Organisasi harus mampu Membangun dan Meningkatkan Kinerja di dalam Lingkungan. Keberadaan Sumber Daya Manusia (SDM) di dalam suatu Organisasi ataupun Perusahaan memegang suatu peranan yang sangat penting. Potensi setiap Sumber Daya Manusia (SDM) yang ada dalam Organisasi atau Perusahaan harus dapat dimanfaatkan dengan sebaik-baiknya sehingga mampu memberikan output yang optimal. Setiap Organisasi maupun Perusahaan akan selalu berusaha untuk meningkatkan Kinerja Karyawannya dengan harapan apa yang menjadi tujuan Perusahaan untuk tercapai.

Sumber Daya Manusia (SDM) sebagai salah satu unsur dalam Organisasi dapat diartikan sebagai Manusia yang Bekerja dalam suatu Organisasi. Sumber Daya Manusia dapat disebut juga sebagai Personil, Tenaga Kerja, Pekerja, Karyawan, Potensi Manusiawi sebagai Penggerak Organisasi dalam mewujudkan eksitensinya atau potensi yang merupakan aset dan berfungsi sebagai modal non material dalam organisasi bisnis, yang dapat diwujudkan menjadi potensi nyata secara fisik dan non fisik dalam mewujudkan eksitensi Organisasi.

(Mondy dan Martocchio, 2008) Mendefinisikan Manajemen Sumber Daya Manusia (MSDM) merupakan proses pencapaian tujuan Organisasi melalui penggunaan Manusia atau individu yang ada di dalamnya, individu atau Karyawan yang dikelola agar memiliki Kompetensi dan Keahlian sesuai yang dibutuhkan dalam mendukung Pekerjaannya. Kemudian menurut (Amstrong dan michael, 2008) Manajemen Sumber Daya Manusia (MSDM) juga 
didefinisikan sebagai pendekatan strategis untuk pengelolaan asset yang paling berharga di dalam Organisasi yaitu Orang yang Bekerja di sana, yang secara individu atau kolektif (tim kerja) berkontribusi terhadap pencapaian sasaran yang telah ditetapkan. Di sini ditekankan pada pengelolaan Manusia tidak saja menjadi tugas para Manager dalam menetapkan tujuan strategis tetapi juga diharapkan peran serta dari Karyawan untuk ikut termotivasi meningkatkan diri demi pencapaian tujuan bersama.

Dari definisi diatas dapat disimpulkan bahwa Manajemen Sumber Daya Manusia (MSDM), adalah suatu proses untuk memperoleh, melatih, menilai, dan mengompensasi karyawan, dan untuk mengurus relasi tenaga kerja mereka, kesehatan dan keselamatan mereka serta hal-hal yang berhubungan dengan keadilan, untuk mewujudkan tujuan-tujuan Organisasi dan Individu.

Kinerja dalam suatu Organisasi dilakukan oleh segenap Sumber Daya Manusia (SDM) dalam Organisasi, baik unsur Pimpinan maupun Pekerja. Setiap Pekerja mempunyai Kemampuan berdasar pada Pengetahuan dan Keterampilan, Kompetensi yang sesuai dengan Pekerjaannya, Kinerja Organisasi juga ditunjukkan oleh bagaimana proses berlangsungnya kegiatan untuk mencapai tujuan tersebut. Di dalam proses pelaksanaan aktivitas harus selalu dilakukan monitoring, Penilaian dan review atau peninjauan ulang terhadap Kinerja Sumber Daya Manusia (SDM). Keberhasilan sebuah Organisasi, tidak terlepas dari baiknya Kinerja Pegawai, dimana tujuan suatu Organisasi akan tercapai dengan baik apabila mempunyai Pegawai atau Sumber Daya Manusia (SDM) yang berkualitas, Sumber Daya Manusia atau SDM adalah proses mendayagunakan Manusia sebagai Tenaga Kerja secara Manusiawi, agar potensi fisik dan psikis yang dimilikinya berfungsi maksimal bagi pencapaian tujuan Organisasi atau Perusahaan.

(Kasmir, 2016) Pengertian Kinerja adalah hasil Kerja dan Perilaku Kerja yang telah dicapai dalam menyelesaikan tugas-tugas dan tanggung jawab yang diberikan dalam suatu priode tertentu. Kemudian Kinerja dapat diukur dari kemampuan menyelesaikan tugas-tugas dan tanggung jawab yang diberikan. Kemampuan seseorang merupakan ukuran pertama dalam meningkatkan Kinerja yang ditunjukan dari hasil Kerjanya. Mampu atau tidaknya seseorang melaksanakan pekerjaannya lah yang menentukan Kinerjanya. Selanjutnya kemampuan ini harus pula diikuti dengan tanggung jawab terhadap pekerjaannya. Secara teori dikatakan bahwa Kinerja juga perlu didukung oleh Motivasi yang kuat agar kemampuan yang dimiliki dapat dioptimalkan. 
Prosiding The 1st National Conference on Applied Business, Education, \& Technology (NCABET)"

Unversitas Bina Bangsa 2021

DOI Article : 10.46306/ncabet.v1i1.1

Merujuk dari pendapat di atas, penulis menyimpulkan bahwa Kinerja adalah hasil kerja seseorang atau kelompok yang dapat diukur sesuai dengan tanggung jawab yang dibebankan kepada individu atau kelompok tersebut.

Strategi adalah Sikap Kepemimpinan yang sangat diperlukan untuk dapat menggerakkan dan memotivasi bawahan untuk melakukan tugasnya dengan sebaik-baiknya. Maka masalah Kepemimpinan tidak dapat dipandang mudah, kemampuan seorang Pemimpin merupakan suatu sarana untuk mencapai tujuan, hal ini berarti bahwa bawahan dalam memenuhi kebutuhannya tergantung pada keterampilan dan kemampuan Pemimpin.

(Setiowati, 2016) Strategi adalah sebuah pola atau rencana yang memadukan Tujuan, Kebijakan, dan serangkaian Tindakan Utama Organisasi menjadi satu kesatuan utuh yang dapat memenuhi kebutuhan para stakeholder. Strategi yang formal mengandung tiga unsur, yaitu: Sasaran Tujuan yang harus dicapai, kebijakan-kebijakan yang memadu atau membatasi tindakan, dan serangkaian aksi atau program untuk mencapai tujuan atau sasaran. Kemudian Strategi menciptakan Kinerja Pegawai yang tinggi menurut (Ilyas, 2001)

a. Meningkatkan Motivasi Kerja

Motivasi Kerja sebagai kesiapan khusus seorang untuk melakukan atau melanjutkan serangkaian Aktivitas yang ditunjukan untuk mencapai beberapa sasaran yang telah ditetapkan, Motivasi Kerja adalah sesuatu hal yang berasal dari internal Individu yang menimbulkan dorongan atau semangat untuk bekerja keras.

b. Meningkatkan Kesejahteraan Pegawai

Pendapatan, Tunjangan dan Gaji, Evaluasi Kinerja sering digunakan sebagai alat untuk meningkatkan Kinerja Personel.

c. Iklim organisasi yang harmonis

Bila terjadi kesenjangan antara apa yang dikerjakan Personel dan apa yang seharusnya ditampilkan untuk memperbaiki Kinerja Personel perlu dilakukan Observasi terhadap penyebab Kinerja yang Sub Optimal tersebut. Untuk memberikan kesempatan kepada Personel bekerja optimal, Organisasi harus menciptakan Lingkungan yang berbeda untuk Personel Profesional.

d. Kepemimpinan yang Efektif, supervisi adalah proses yang memacu Anggota unit Kerja untuk Berkontribusi secara positif agar tujuan Organisasi tercapai.

e. Pengembangan Karir

Penilaian Kinerja seharusnya merupakan pengamanan positif yang memberikan Motivasi dan Pengembangan Personel. Penilaian Personel harus mengidentifikasikan 
tujuan utama mereka yang dapat dicapai dan memperhatikan juga kebutuhan personel untuk tumbuh kembang secara Profesional.

Maka dapat disimpulkan bahwa, strategi merupakan suatu cara di mana sebuah Lembaga Organisasi akan mencapai tujuannya dan sasaran dalam jangka panjang. Dalam pengaplikasiannya, strategi membutuhkan peran banyak Orang dan membutuhkan Kerjasama Tim untuk mencapai tujuan dengan optimal.

Dalam konteks Sistem Pemerintahan Negara Kesatuan Republik Indonesia yang membagi Daerah Indonesia atas Daerah-Daerah besar dan Daerah kecil, dengan bentuk dan susunan tingkatan Pemerintahan terendah adalah Desa atau Kelurahan. Dalam konteks ini, Pemerintahan Desa adalah merupakan subsystem dari system penyelenggaraan Pemerintah Nasional yang langsung berada di bawah Pemerintah Kabupaten. Desa dapat didefinisikan sebagai kesatuan Masyarakat Hukum yang memiliki batas-batas Wilayah yang mempunyai kewenangan untuk mengatur dan mengurus kepentingan Masyarakat setempat berdasarkan asal-usul dan Adat Istiadat setempat yang diakui dan dihormati dalam Sistem Pemerintahan Negara Kesatuan Republik Indonesia.

Desa Nagara merupakan salah satu Desa dari sembilan Desa di Wilayah Kecamatan Kibin Kabupaten Serang, yang berada pada ketinggian \pm 500 meter di atas Permukaan Laut dengan luas Wilayah 1210 Ha. Dengan batas-batas sebagai berikut : Sebelah Utara berbatasan dengan Desa Cijeruk Kecamatan Kibin, sebelah Timur berbatasan dengan Desa Pakusaji Kecamatan Bandung, sebelah Selatan berbatasan dengan Desa Blokang Kecamatan Bandung, sebelah Barat berbatasan dengan Desa Dukuh Kecamatan Kragilan. Berdasarkan Peraturan Pemerintahan Republik Indonesia Nomor 73 Tahun 2005 tentang Kelurahan yang menterjemahkan bahwa Kelurahan merupakan dasar dari satuan Pemerintahan yang terkecil dari suatu Komunitas Pemerintahan Negara. Untuk meningkatkan Pelayanan Masyarakat dan melaksanakan fungsi-fungsi Pemerintahan di Perkotaan, perlu dibentuk Kelurahan untuk mempercepat terwujudnya Kesejahteraan Masyarakat guna menjamin penyelenggaraan Pemerintahan Kelurahan.

Dengan melihat tugas pokok dan fungsi Strategis dari adanya Desa di dalam sebuah Kabupaten tentunya peran dari seorang pemimpin sangatlah penting. Bagaimana Strategi yang digunakan sebagai upaya untuk senantiasa meningkatkan Kinerja Pegawai yang ada di Ruang Lingkup Kerja tersebut. Oleh karena itu, diperlukan suatu Kemauan dan Kesanggupan untuk mempengaruhi Opini, Sikap dan Tingkah Laku Orang Lain agar mau melakukan sesuatu Pekerjaan secara profesional. 
Prosiding The 1st National Conference on Applied Business, Education, \& Technology (NCABET)"

Unversitas Bina Bangsa 2021

DOI Article : 10.46306/ncabet.v1i1.1

Pemimpin disini yang dimaksud adalah Kepala Desa Nagara Kecamatan Kibin Kabupaten Serang. Dimana dalam Kepemimpinanya perlu menggunakan Strategi, Strategi merupakan respons secara terus menerus maupun adaptif terhadap peluang dan ancaman eksternal serta kekuatan dan kelemahan internal yang dapat mempengaruhi Organisasi. Strategi inilah yang digunakan Pemimpin dalam melaksanakan proses Kepemimpinannya di Instansi guna meningkatkan Kinerja Pegawai.

Kepemimpinan Kepala Desa Nagara Kecamatan Kibin Kabupaten Serang sangatlah berperan penting dalam seluruh Kegiatan Birokrasi yang ada di Kantor Desa tersebut. Pentingnya Kinerja Pegawai pada suatu Organisasi Pemerintahan seperti Kantor Desa Nagara Kecamatan Kibin Kabupaten Serang merupakan salah satu unsur dalam pencapaian tujuan pelayanan yang maksimal kepada Masyarakat, tentunya dalam hal ini Strategi Kepala Desa Nagara Kecamatan Kibin Kabupaten Serang tersebut sangatlah berpengaruh terhadap Kinerja Pegawai. Penulis menemukan Masalah di dalam Laporan Penyelenggaraan Pemerintah Daerah Desa Nagara (LPPD) yaitu berbanding terbalik dengan Kinerja yang dilakukan oleh Oknum Pegawai Kantor Desa Nagara Kecamatan Kibin ini. Kinerja yang tidak optimal pastinya akan berpengaruh terhadap Pelayanan Kepada Masyarakat, tentunya Masyarakat tidak puas atas Pelayanan yang telah diberikan oleh Pegawai. Aparatur Desa merupakan pilar utama dalam Pembangunan khususnya Pembangunan di Wilayah Desa Nagara, profesional mengandung artian menguasai dan memahami segala tugas-tugasnya yang menjadi tanggung jawabnya, sehingga segala urusan dapat dilaksanakan dengan sebaik-baiknya sesuai tujuan organisasi, Aparatur Desa merupakan Pelayan Masyarakat yang senantiasa dapat memberikan Pelayanan secara Prima. Pelayanan Prima mengandung artian bahwa Pelayanan yang diberikan kepada Masyarakat memiliki tingkat Kepuasan Masyarakat yang sangat tinggi, dengan mempertimbangkan waktu Pelayanan yang cepat, biaya murah, dan prosedur mudah.

Kepemimpinan Kepala Desa Nagara Kecamatan Kibin Kabupaten Serang sangatlah berperan penting dalam seluruh Kegiatan Birokrasi yang ada di Desa tersebut. Pentingnya Kinerja Pegawai pada suatu Organisasi Pemerintahan seperti Kantor Desa Nagara Kecamatan Kibin Kabupaten Serang merupakan salah satu unsur dalam pencapaian tujuan Pelayanan yang maksimal kepada Masyarakat.

Peneliti melihat banyak masalah-masalah di instansi tentang Strategi Kepala Desa Nagara, diantaranya (1) Kurang optimalnya Kinerja Pegawai kepada masyarakat sehingga masyarakat tidak puas atas pelayanan yang diberikan Pegawai Kantor Desa Nagara, (2) Belum diadakan rapat rutin Internal Kantor Desa Nagara sehingga tidak bisa mengevaluasi Kinerja 
Pegawai, (3) Kurangnya sarana dan prasarana di Kantor Desa Nagara sehingga pelayanan kurang optimal, (4) Belum diadakan system reward dan punishment (penghargaan dan peringatan), sehingga Pegawai masih belum tertib aturan, (5) Belum adanya Kemitraan Kantor Desa Nagara dengan Instansi yang lain untuk Pelatihan sehingga Keterampilan Pegawai kurang memadai.

Dari fenomena yang ada peneliti berfikir sangat perlu dilakukan Strategi Kepala Desa dalam meningkatkan Kinerja Pegawai untuk meningkatkan kualitas para pegawai itu sendiri serta diharapkan optimalnya pelayanan kepada masyarakat.

Bertitik tolak dari uraian diatas, peneliti tertarik untuk melakukan penelitian dengan judul "Strategi Kepala Desa Dalam Meningkatkan Kinerja Pegawai Di Kantor Desa Nagara Kecamatan Kibin Kabupaten Serang.

\section{METODE PENELITIAN}

Penelitian ini merupakan jenis penelitian kualitatif, pendekatan yang digunakan adalah deskriptif dengan berlandaskan pada teori fenomenologi. Menurut (Sugiyono, 2009), menjelaskan tentang metode kualitatif, bahwa Metode Penelitian yang berlandaskan pada filsafat post-positivisme, digunakan untuk meneliti pada kondisi obyek yang alamiah, dimana peneliti adalah instrumen kunci. Kemudian menurut (Arkunto, 2005), penelitian deskriptif tidak dimaksudkan untuk menguji hipotesis tertentu, tetapi hanya untuk menggambarkan apa adanya suatu variabel, gejala, atau kejadian.

Penulis dalam hal ini menggunakan infroman yang berasal dari pegawai yang bekerja di Kantor Desa Nagara Kecamatan Kibin Kabupaten Serang yaitu Kepala Desa sebagai key informan, KAUR Perencanaan dan Pelaporan, KASI Pelayanan, KAUR Umum. Sumber data utama dicatat melalui catatan utama atau melalui rekaman atau foto-foto.

Pencatatan sumber data utama melalui wawancara atau pengamatan merupakan hasil gabungan dari kegiatan melihat, mendengar dan bertanya. Untuk sumber data sekunder adalah literatur-literatur yang ada di perpustakaan maupun di kearsipan di Kantor Desa Nagara Kecamatan Kibin Kabupaten Serang. Adapun alat yang digunakan yaitu peneliti itu sendiri terjun ke Lapangan. Untuk mengumpulkan data penelitian maka digunakan teknik Observasi, Interview (Wawancara), dan Dokumentasi.

\section{HASIL DAN PEMBAHASAN}


Prosiding The 1st National Conference on Applied Business, Education, \& Technology (NCABET)"

Unversitas Bina Bangsa 2021

DOI Article : 10.46306/ncabet.v1i1.1

"Strategi Kepala Desa Dalam Meningkatkan Kinerja Pegawai Di Kantor Desa Nagara Kecamatan Kibin Kabupaten Serang”.

Untuk melihat Strategi yang digunakan oleh Kepala Desa Nagara dalam meningkatkan kinerja pegawainya, maka penulis telah melakukan wawancara dengan informan yaitu Kepala Desa, KAUR Perencanaan dan Pelaporan, KASI Pelayanan dan KAUR Umum di Kantor Desa Nagara Kecamatan Kibin Kabupaten Serang, wawancara ini dilakukan pada tanggal 23 Juni sekitar pukul 15.00 WIB dan tanggal 25 Juli sekitar pukul 20.00 WIB, penulis telah melakukan wawancara dengan Kepala Desa Nagara Kecamatan Kibin Kabupaten Serang selaku Key Informan. Untuk melihat Strategi yang digunakan oleh Kepala Desa Nagara dalam meningkatkan kinerja di Kantor Desa Nagara Kecamatan Kibin Kabupaten Serang, penulis mengacu pada teori Kuncoro (2006: 7), yang meliputi :

\section{Analisis}

Analisis dapat diartikan pekerjaan penelaah secara mendalam yang dapat memberikan keterangan tentang tugas, tanggung jawab dan sifat pekerjaan agar dapat melaksanakan pekerjaan itu dengan baik dan dapat menentukan manfaat dari kegiatan yang dilaksanakan. Adapun indikator yang bisa dilihat dari analisis adalah :

a. Rapat rutin internal Kantor Desa

Adalah mengadakan rapat rutin internal secara rutin dan berkesinambungan dengan membahas permasalahan-permasalahan yang penting dan sebagai bahan evaluasi dari kinerja. Rapat rutin internal sudah terlaksana dengan baik di Kantor Desa Nagara walaupun untuk waktunya tidak menentu bisa seminggu sekali bahkan satu bulan sekali diadakan rapat rutin, hal ini dilihat tidak adanya agenda rapat rutin yang diadakan di Kantor Desa Nagara, penulis hanya menemukan undangan rapat yang membahas tentang evaluasi kegiatan-kegiatan yang telah dilaksanakan, evaluasi kinerja pegawai, tingkat kedisiplinan pegawai.

\section{b. Struktur Organisasi}

Yang dimaksud Struktur Organisasi disini yaitu suatu alat yang digunakan untuk memberikan arah, petunjuk maupun tata pembagian pekerjaan didalam melaksanakan tugas. Sudah adanya Struktur Organisasi di Kantor Desa Nagara Kecamatan Kibin Kabupaten Serang yang berjalan dengan fungsinya dan ditempel ditembok pintu masuk Kantor Desa Nagara. Namun dilihat dari kuantitas pegawai yang ada di Kantor Desa tersebut, maka semua pegawai juga saling berbagi kerja atau team work.

c. Sarana dan Prasarana 
Sarana dan Prasarana Kantor Desa dapat diartikan bahwa suatu alat yang digunakan yang bisa difungsikan didalam melaksanakan pekerjaan dan merupakan faktor penunjang yang sangat penting didalam suatu organisasi. Sarana dan Prasarana yang ada di Kantor Desa Nagara Kecamatan Kibin Kabupaten Serang sudah lengkap dengan adanya AC dan printer disetiap ruangan, adanya ruang kepala desa beserta fasilitasnya, kemudian dapur untuk menunjang kebutuhan pokok, ada juga meja pelayanan untuk menunjang pelayanan yang optimal kemudian adanya aula tempat rembuk warga, semuanya sudah lengkap tersedia di Kantor Desa Nagara Kecamatan Kibin Kabupaten Serang.

\section{Keputusan}

Secara garis besar keputusan dapat diartikan bahwa hasil pemecahan masalah yang dihadapi dengan tegas. Apa yang harus dilakukan oleh Kepala Desa Nagara Kecamatan Kibin Kabupaten Serang mengenai perencanaan-perencanaan yang bersifat memotivasi kerja yang tinggi pada pegawai. Indikator yang dapat dilihat sebagai berikut :

a. Disiplin Pegawai

Disiplin pegawai dapat diartikan bahwa suatu bentuk sikap yang harus mematuhi peraturan yang telah disepakati atau aturan yang telah ditentukan. Disiplin pegawai di Kantor Desa Nagara Kecamatan Kibin Kabupaten Serang sudah bagus dengan adanya tata tertib yang tertulis walaupun belum menggunakan finger print dengan terus mengadakan evaluasi terhadap tingkat kedisiplinan pegawai.

b. Reward dan Punishment

Reward bisa diartikan sebagai hadiah yang diberikan kepada pegawai sebagai bentuk penghargaan atas prestasi yang sudah diraih sebagai motivasi. Sedangkan punishment merupakan hukuman atau sanksi yang diberikan kepada pegawai yang tidak mentaati aturan yang diberlakukan di suatu organisasi. Reward dan Punishment di Kantor Desa Nagara Kecamatan Kibin Kabupaten Serang bahwa sekali-kali ada reward yang diberikan seperti penambahan honor kegiatan dan ucapan secara lisan, untuk reward yang lebih daripada itu belum pernah ada di Kantor Desa Nagara. Sedangkan untuk punishment atau sanksi hanya ada teguran saja tidak adanya pemberian hukuman yang berat.

c. SDM yang berkualitas

SDM yang berkualitas dapat diartikan bahwa pegawai yang bekerja di Kantor Desa Nagara Kecamatan Kibin Kabupaten Serang berkualitas, memiliki kemampuan, mempunyai 
Prosiding The 1st National Conference on Applied Business, Education, \& Technology (NCABET)"

Unversitas Bina Bangsa 2021

DOI Article : 10.46306/ncabet.v1i1.1

skill, invovasi dan mampu mencari solusi yang cepat dan tepat ketika menghadapi suatu masalah. Sumber Daya Manusia yang berkualitas dapat dilihat dengan harus banyak diadakan pelatihan dan belajar terus agar bisa bekerja secara efektif dan efisien, meningkatkan kedisiplinan, mempunyai ide-ide yang cemerlang dan juga tingkatan pendidikan seseorang pegawai tersebut.

\section{Aksi}

Aksi dapat diartikan bahwa tindakan yang dilakukan oleh Kepala Desa Nagara berdasarkan situasi tertentu untuk mencapai apa yang menjadi tujuan dan sasaran dengan sarana yang paling tepat di Kantor Desa Nagara Kecamatan Kibin Kabupaten Serang. Indikatornya adalah :

a. Kemitraan dengan instansi yang lain

Dalam hal ini, Kantor Desa mengadakan kerjasama dengan beberapa instansi sebagai wadah pengembangan, dengan demikian apapun masalah yang dihadapi tersebut akan mudah teratasi. Kemitraan Kantor Desa Nagara Kecamatan Kibin Kabupaten Serang dengan instansi yang lain yaitu mengadakan kerjasama dengan Dinas Pertanian yang memberikan bantuan penyaluran irigasi kepada para petani.

b. Peningkatan Kuantitas Pegawai

Dalam hal ini bisa diartikan bahwa jumlah pegawai di Kantor Desa Nagara Kecamatan Kibin Kabupaten Serang apakah sudah sesuai kebutuhan dan bekerja sesuai dengan tugas pokok dan fungsinya. Kuantitas Pegawai di Kantor Desa Nagara sudah mencukupi, dilihat dari daftar kebutuhan pegawai di Kantor Desa Nagara.

c. Pengembangan Keterampilan Pegawai

Yang dimaksudkan dengan pengembangan keterampilan pegawai disini yaitu upaya-upaya yang dilakukan oleh Kepala Desa Nagara Kecamatan Kibin Kabupaten Serang dalam mengembangkan kemampuan-kemampuan yang ada pada pegawainya. Peningkatan keterampilan pegawai yaitu sudah adanya pelatihan dengan BPD serta study banding keluar daerah.

\section{KESIMPULAN}

Sebagaimana hasil dari analisa yang mengacu dari informasi-informasi yang didapat dari Wawancara, Observasi, serta literatur kepustakaan, maka penulis membuat beberapa kesimpulan yang merupakan jawaban dari perumusan masalah. Adapun kesimpulan dalam penelitian ini yaitu: 
1. Untuk membahas evaluasi kinerja yang telah dilaksanakan di Kantor Desa Nagara Kecamatan Kibin Kabupaten Serang mengadakan rapat rutin internal walaupun tidak ditentukan waktunya yaitu bisa seminggu sekali dan bisa satu bulan sekali agar dapat melaksanakan pekerjaan itu dengan baik dan dapat menentukan manfaat dari kegiatan yang dilaksanakan di Kantor Desa Nagara Kecamatan Kibin Kabupaten Serang, evaluasi Kinerja Pegawai, tingkat kedisiplinan pegawai dan juga pelayanan kepada masyarakat sekitar. Untuk sarana dan prasarana sudah lengkap, namun banyak pegawai yang merokok di Dalam ruangan yang ber AC.

2. Untuk memberikan arah, petunjuk maupun tata pembagian tugas di Kantor Desa Nagara Kecamatan Kibin Kabupaten Serang sudah ada Struktur Organisasi yang di tempel di pintu masuk Kantor Desa Nagara. Sudah adanya tata tertib di Kantor Desa Nagara, disiplin pegawai sudah bagus, walaupun belum menggunakan finger print dengan terus mengadakan evaluasi terhadap tingkat kedisiplinan pegawai, walaupun hanya secara lisan diucapkan oleh Kepala Desa sebagai punishment dan sesekali diberlakukan reward bagi pegawai yang berprestasi. meningkatkan Sumber Daya Manusia yang berkualitas dengan harus banyak diadakan pelatihan, di Kantor Desa Nagara sudah di adakan pelatihan seperti pelatihan dengan BPD dan Karang Taruna.

3. Kebijakan Kepala Desa untuk mencapai tujuan dan sasaran yaitu menjalin kemitraan Kantor Desa Nagara Kecamatan Kibin Kabupaten Serang dengan instansi yang lain yaitu mengadakan kerjasama dengan Basarnas, PT.Nikomas yang sering memberi bantuan serta Dinas Pertanian yang sudah memberikan bantuan berupa irigasi untuk persawahan para petani di Desa Nagara, Kepala Desa juga mengadakan pengembangan keterampilan, dan untuk Kuantitas Pegawai di Kantor Desa di bilang cukup sehingga tidak ada penambahan lagi.

\section{UCAPAN TERIMAKASIH}

Ucapan terimakasih kepada pihak-pihak yang membantu dala penelitian ini, khususnya pada instansi Kantor Desa Nagara Kecamatan Kibin Kabupaten Serang

\section{DAFTAR PUSTAKA}

Arikunto, Suharsimi, 2005, Manajemen Penelitian, Jakarta : Rineka Cipta.

Armstrong, Michael, 2008, Strategic

human resource management: a guide to action - 4th editions, London : Kogan Page Limited. 
Prosiding The 1st National Conference on Applied Business, Education, \& Technology (NCABET)"

Unversitas Bina Bangsa 2021

DOI Article : 10.46306/ncabet.v1i1.1

Dokumentasi Laporan Pemerintahan Desa LPPD (Desa Nagara, 2020). Dokumentasi Laporan Kegiatan Pemerintah Desa LKPD Akhir Tahun Anggaran 2020, (Pemerintah Kabupaten Serang, 2020).

Ilyas, 2001, Teori Penilaian dan Penelitian Kinerja, Jakarta : Pusat Kajian Ekonomi Kesehatan.

Kasmir, 2016, Manajemen Sumber Daya Manusia, Jakarta : Rajawali Press.

Mondy, R. Wayne dan Joseph J.Martocchio, 2016, Human Resource Management Fourteenth Edition -Global Edition, England : Pearson Education Limited.

Setiowati, Reni Diah Ayu, 2016, "Strategy Social Entrepreneurship Dalam Mewujudkan Kemandirian Lembaga Social Islam (Study Kasus Yayasan Nurul Hayat Surabaya)" Surabaya : Universitas Islam Negeri Sunan Ampel Surabaya.

Sugiyono, 2009, Metode Penelitian Kuantitatif, Kualitatif R\&D, Bandung : Alfabeta. 